\title{
Market Channels of Technology Startups that Internationalize Rapidly from Inception Simar Yoos
}

\author{
"Most of the things worth doing in the world have been") \\ declared impossible before they were done.
}

Louis Dembitz Brandeis (1856-1941)

U.S. Supreme Court Justice

\begin{abstract}
The study of technology startups that internationalize rapidly from inception has increased in recent years. However, little is known about their channels to market. This article addresses a gap in the "born global" literature by examining the channels used by six startups that internationalized rapidly from inception as well as the programs they used to support their channel partners and customers. The six startups examined combined the use of the Internet with: i) a relationship with a multi-national, ii) distributors, iii) resellers, or iv) a direct sales force. They also delivered programs to support partners and customers that focused on communications, alliance and network development, education, marketing and promotion, and financial incentives.

This article informs entrepreneurs who need to design go-to-market channels to exploit global opportunities about decisions made by other entrepreneurs who launched bornglobal companies. Normative rules and practitioner-oriented approaches are needed to help entrepreneurs explain and apply the results presented in this article.
\end{abstract}

\section{Introduction}

Startups that internationalize rapidly from inception are referred to as "born globals." These born globals are different from traditional startups in terms of their growth processes. While born globals internationalize rapidly from inception, conventional approaches to internationalization stress the pre-engagement phase of a startup, during which a startup first develops its domestic market and then thinks about selling abroad.

According to Gabrielsson and Kirpalani (2012; tinyurl.com/916509b), born globals: i) perform better than startups that follow the conventional approach to internationalization; ii) use the Internet extensively; iii) target homogeneous customers that are concentrated globally; iv) offer very innovative products and services; v) are very effective at levering networks and business ecosystems; and vi) exhibit a greater entrepreneurial orientation than other firms. What we do not know is what channels to market, in addition to the Internet, born globals use and how they support their channel partners.

A channel to market is a set of interdependent organizations involved in the process of making a product or service available for use or consumption (Tybout and Calder, 2010; tinyurl.com/9hqhwnp). Servais, Madsen, and Rasmussen (2006; tinyurl.com/9cn3z4g) examine the global expansion of born-global firms and their use of the Internet as a channel to market. They conclude that born-global firms rely on the Internet more intensely than other firms.

Technology startups that internationalize rapidly from inception require relationships with individuals and 


\section{Market Channels of Technology Startups that Internationalize Rapidly from Inception}

\section{Simar Yoos}

organizations in the host country to overcome local market barriers and enter new markets (Johanson and Vahlne, 2003; tinyurl.com/8mljm7z). Reputation and cooperation with individuals and organizations in host countries are important for internationalization (Kotha et al., 2010; tinyurl.com/9b68kq5). In addition, born globals may leverage the channels and networks of large companies to expand rapidly (Coviello and Munro, 1997: tinyurl.com/955p49s; Grabrielsson et al., 2008: tinyurl.com/998amz9).

Therefore, examining "social ties independently of inter-organizational networks" (Ellis, 2008; tinyurl.com/ 9heekay) is important. Marlova, Manev, and Gyoshev (2010; tinyurl.com/9f5vbmo) confirm that networks are essential links to internationalization. They highlight the critical role that interpersonal ties have on alliance formation.

This article addresses a gap in the born-global literature by identifying: i) the channels to market used by six technology startups that internationalized rapidly and ii) the programs that they delivered to support their channel partners (i.e., support programs). Entrepreneurs can use the results to learn about decisions made by founders of born-global companies.

The article is organized as follows. The next section reviews what is known about channels to market as they pertain to born-global firms. Following this, the channels to market and partner-support programs of six startups are identified. The last section provides the conclusions.

\section{Channels to Market}

Gabrielsson and Kirpalani (2004; tinyurl.com/cnmtekt) suggest that startups that internationalize rapidly mainly rely on two channels to market: i) the Internet and ii) a relationship with a large multinational firm where both the startup and the large firm are both dependent on the outcome. Gabrielsson and Gabrielsson (2010; tinyurl.com/8d7sc6b) concluded that: i) the frequency of Internet-based channel usage increases during the globalization process of the firm; ii) most firms use an Internet-based sales strategy based on a multiple-channel approach; and iii) the use of the Internet as a channel to market is more common among business-to-consumer than business-tobusiness firms. However, the greater usage of the Internet as a channel to market can often be explained by the digital nature of the products sold by firms, such as software and digital services.
The complexity of the market offering, and the extent to which it must be customized and configured in the sales process, affects channel selection and the programs a firm delivers to support its channel partners. Highly-customized offerings require the firm to deliver extensive configuration, design, training, support, and advice to customers and channel partners throughout the sales process. As a result, complex offerings must be sold through "high-touch" channels (e.g., field sales representatives, value-added partners), who are able to provide face-to-face interaction and guidance. Conversely, simple products that require minimal, if any, customization, training, support, or advice can usually be sold through "low-touch" channels, with little or no face-to-face support and interaction. Low-touch channels can reach more customers at a lower cost.

\section{Examination of Six Technology Startups}

The author set out to identify the channels to market used by born-global firms as well as the programs they used to support their channel partners. For this purpose, the channels to market of six born-global companies were examined during their first three years after inception.

Each of the six technology startups examined: i) started exporting in the first 12 months after inception; ii) generated more than 50 percent of total sales through foreign customers and created more than six knowledge jobs three years after inception; and iii) were founded between 2002 and 2009. Moreover, none of these startups was a large-firm spinoff or a joint venture of large firms. All six companies operated independently for three years after inception without being acquired.

Table 1 identifies the six technology startups examined. For each startup, Table 1 provides the country and year in which they were founded, and brief descriptions of their market offers. Table 1 shows that the six startups were established in five countries: Australia, Brazil, Colombia, Israel, and the United States. Three of these firms were founded in 2002, one in 2005, and two in 2008. The sample included business-to-business and business-to-consumer companies.

\section{Channels to Market}

The channels to market used by the six startups examined were organized into five channel types: Internet, Relationship with multinational, Distributors 


\section{Market Channels of Technology Startups that Internationalize Rapidly from Inception}

\section{Simar Yoos}

Table 1. The six technology firms in the sample

\begin{tabular}{lllll}
\hline Company & Website & $\begin{array}{l}\text { Country } \\
\text { of Origin }\end{array}$ & $\begin{array}{l}\text { Year } \\
\text { Founded }\end{array}$ & Market offer \\
\hline Atlassian & atlassian.com & Australia & 2002 & Software tools for programmers working on base code \\
\hline Dewak S.A. & dewak.com & Colombia & 2008 & Custom development of help desk software products \\
\hline $\begin{array}{l}\text { Griaule } \\
\text { Biometrics }\end{array}$ & griaulebiometrics.com & Brazil & 2002 & $\begin{array}{l}\text { Software products to identify people on the basis of unique } \\
\text { fingerprint features }\end{array}$ \\
\hline $\begin{array}{l}\text { NOJA Power } \\
\text { Switchgear }\end{array}$ & NOJApower.com.au & Australia & 2002 & Low- and medium-voltage technology switchgear products \\
\hline $\begin{array}{l}\text { Sproxil } \\
\text { Tufin }\end{array}$ & sproxil.com & USA & 2008 & $\begin{array}{l}\text { File hosting service offering cloud storage, file synchronization, } \\
\text { and client software }\end{array}$ \\
\hline
\end{tabular}

(Direct sales channels), Re-sellers (Indirect channels), and Direct sales force. Table 2 shows that none of the six startups combined all five channel types. It also shows that all six technology startups used the Internet as a channel to market; however, only two of the six startups used a relationship with a large multinational as a channel to market (Dewak S.A. and Sproxil).

Four startups relied on three channels, one of which was the Internet (Griaule Biometrics, Noja Power
Switchgear, Sproxil, and Tufin). Two startups relied on two channels, one of which was the Internet (Atlassian and Dewak S.A.).

None of the six startups used distributors or re-sellers in combination with the Internet and a relationship with a multinational.

Only one company (Dewak S.A.) relied solely on the Internet and a relationship with a large multinational as

Table 2. Channels to market used by six firms in the sample

\begin{tabular}{|c|c|c|c|c|c|c|}
\hline Channel Type & Atlassian & Dewak S.A. & $\begin{array}{l}\text { Griaule } \\
\text { Biometrics }\end{array}$ & $\begin{array}{l}\text { NOJA Power } \\
\text { Switchgear }\end{array}$ & Sproxil & Tufin \\
\hline Internet & Direct sales & $\begin{array}{l}\text { Direct sales; } \\
\text { online forums } \\
\text { for customer } \\
\text { identification }\end{array}$ & Direct sales & $\begin{array}{l}\text { Direct sales; } \\
\text { telecom } \\
\text { support for } \\
\text { local } \\
\text { providers }\end{array}$ & $\begin{array}{l}\text { Direct sales; } \\
\text { telecom } \\
\text { support to } \\
\text { customers }\end{array}$ & $\begin{array}{l}\text { Direct sales; } \\
\text { telecom } \\
\text { support to } \\
\text { customers }\end{array}$ \\
\hline $\begin{array}{l}\text { Relationship with } \\
\text { multinational }\end{array}$ & & Kayako & & & IBM & \\
\hline $\begin{array}{l}\text { Distributors } \\
\text { (Direct sales } \\
\text { channels) }\end{array}$ & & & $\begin{array}{l}\text { Around } \\
\text { the world }\end{array}$ & $\begin{array}{l}\text { Around } \\
\text { the world }\end{array}$ & & $\begin{array}{l}\text { Around } \\
\text { the world }\end{array}$ \\
\hline $\begin{array}{l}\text { Re-sellers } \\
\text { (Indirect channels) }\end{array}$ & & & $\begin{array}{l}\text { Around } \\
\text { the world }\end{array}$ & & & \\
\hline Direct sales force & $\begin{array}{l}\text { Sales offices } \\
\text { around the } \\
\text { world }\end{array}$ & & & $\begin{array}{l}\text { Sales offices } \\
\text { around the } \\
\text { world }\end{array}$ & $\begin{array}{l}\text { Sales offices } \\
\text { in Africa, } \\
\text { India, and the } \\
\text { USA }\end{array}$ & $\begin{array}{l}\text { Sales offices } \\
\text { in Europe, } \\
\text { Asia Pacific, } \\
\text { and North } \\
\text { America }\end{array}$ \\
\hline
\end{tabular}




\section{Market Channels of Technology Startups that Internationalize Rapidly from Inception}

\section{Simar Yoos}

its channels to market. It was the only startup of the six shown in Table 2 that offered custom software development.

These findings are consistent with studies that found that the Internet does not replace face-to-face sales (Gabrielsson and Gabrielsson, 2010: tinyurl.com/8d7sc6b; Moen et al., 2003: tinyurl.com/9enlltx).

\section{Partnership Programs and Website Features Used to Support Them}

Table 3 shows that three of the six startups examined operated partnership programs. Table 3 shows that a variety of features in the startups' websites were used to support partnership programs.

Table 3. Features in the websites of the six technology startups that supported channel partners

\begin{tabular}{ll}
\hline Startup & Website Features \\
\hline Atlassian & - Product blog mentions \\
& - Social media mentions \\
& - Email newsletter \\
& - Joint webinars \\
\hline Dewak S.A. & - Nounch event marketing \\
\hline Griaule & - R\&D investment and technical support \\
Biometrics & - Limited information in public side of the \\
& $\begin{array}{l}\text { website, sign-up process is required to } \\
\text { obtain information }\end{array}$ \\
\hline - No partnership programs \\
\hline Switchgear
\end{tabular}

\section{Channel Support Programs}

The support programs the six startups delivered to their channel partners and customers were organized into the following eight categories:

1. Educational: training, clinics, open houses

2. Networks and Alliances: social ties, inter-firm (business) networks

\section{Promotional: contests, salesperson bonuses}

4. Logistical: physical inventory levels, national and regional warehousing

5. Commitment: channel partners are supported by all management levels

6. Communications: advisory councils, field bulletins, newsletters, performance evaluations, electronic data, interchange

7. Financial: payment terms, credit, leasing, returns, discounts

8. Marketing: direct mail, qualified leads, exhibitions, cash on delivery, marketing plan, advertising

The eight categories of support programs combined those identified by Rolnicki (1998; tinyurl.com/9ozgtto), Coviello and Munro (1997; tinyurl.com/9vyyebz), and Gabrielsson and colleagues, (2008; tinyurl.com/998amz9).

The categories were rated based on the frequency in which startups delivered one or more support programs in the category during the first three years from inception. For each of the eight categories, Table 4 identifies the specific support programs delivered and the number of startups that delivered at least one support program within that category.

Table 4 shows that all six startups delivered communication programs to support their channel partners and customers. Of the six startups, four delivered support programs in three categories: networks, education, and marketing. Three startups delivered support programs in the promotional category. None of the six startups delivered support programs in the logistical and commitment categories. 


\section{Market Channels of Technology Startups that Internationalize Rapidly from Inception}

Simar Yoos

Table 4. Programs to support channel partners and customers delivered by six startups

\begin{tabular}{|c|c|c|}
\hline Category & Support Program & Number of Startups \\
\hline Communications & $\begin{array}{l}\text { - } \quad \text { Present website in multiple languages } \\
\text { - } \text { Skyperact using Facebook, Twitter, Google+, Blogs, Feed Center, } \\
\text { - } \quad \text { Meet face to face to support large projects } \\
\text { - } \quad \text { Provide remote access to human resources } 24 \times 7 \\
\text { - } \quad \text { Prepare product reviews }\end{array}$ & 6 \\
\hline $\begin{array}{l}\text { Networks and } \\
\text { Alliances }\end{array}$ & $\begin{array}{l}\text { - Establish a network to acquire information on local markets, } \\
\text { economic environment, regulations, competitors, business, and } \\
\text { culture } \\
\text { - } \quad \text { Partner with internationally renowned clients } \\
\text { - Secure referrals from well-established organizations } \\
\text { - Partner with leading vendors }\end{array}$ & 4 \\
\hline Educational & $\begin{array}{l}\text { - Establish a university relationship } \\
\text { - Deliver technical training } \\
\text { - Provide access to trainers and other educational resources } \\
\text { - Deliver a certification program }\end{array}$ & 4 \\
\hline Marketing & $\begin{array}{l}\text { - Provide marketplace visibility, mention products in blogs and } \\
\text { social media, or organize launch events } \\
\text { - Attract leads from customers' websites } \\
\text { - Place company links on clients' websites } \\
\text { - Invest in joint events, webinars, and lead-generation campaigns } \\
\text { - Deliver free post-sales services }\end{array}$ & 4 \\
\hline Promotional & $\begin{array}{l}\text { - Design and deliver co-promotional campaigns } \\
\text { - Provide free access to tools } \\
\text { - Provide free licenses } \\
\text { - Provide tools to locate company's partners }\end{array}$ & 3 \\
\hline Financial & - Offer price discounts & 2 \\
\hline Logistical & & 0 \\
\hline Commitment & & 0 \\
\hline
\end{tabular}




\section{Market Channels of Technology Startups that Internationalize Rapidly from Inception}

\section{Simar Yoos}

\section{Conclusion}

This article identified the market channels and corresponding support programs of six technology startups that internationalized rapidly from inception. Tables 2 and 4 inform entrepreneurs about the market channels and channel support programs of the six startups.

All six of the technology startups examined used the Internet for sales; however, five of the six startups relied on additional channels to reach international markets. This suggests that born globals need to go beyond using the Internet to internationalize early and rapidly.

The six startups examined also provided a variety of programs to support their market channels. While all six startups delivered communication programs, only four of the startups delivered programs focused on networks, education, and marketing.

Many entrepreneurs are able to take what is a great idea on paper, support it with well-prepared presentations, and secure access to grants or funding. However, they often then attempt to go straight to market without identifying their market channels and channel support programs. Overlooking these key steps can put the entire venture at risk. Equally, many entrepreneurs are tempted to internationalize rapidly by using only the Internet. The results presented here suggest that this is not enough; rapid internationalization requires a variety of channels from the start to market on a number of fronts.

Entrepreneurs can use the results of this study to identify the market channel options available to them and prioritize their investments in the programs required to support their partners and customers. However, more research is needed before entrepreneurs can effectively explain and apply the observations provided in this article. Normative rules and practitioner-oriented approaches are needed. For example, we need to identify the factors that influence a born global to select a specific combination of channels to market over other combinations (e.g., why and when will a born global use a direct sales force instead of a combination of distributors and resellers?). We also need to understand whether the nature of a startup's business affects the combination of channels to market it uses. For instance, can a startup that is not a custom software developer follow the example of Dewak S.A. and use only the Internet and a relationship with a multinational company? Further research to develop normative rules and practitioner-oriented approaches would help us find answers to such questions.

\section{About the Author}

Simar Yoos has 15 years of experience launching and growing companies as well as helping international companies to solve commercialization-related conflicts. He is currently completing his MASc degree in Technology Innovation Management at Carleton University in Ottawa, Canada. His research examines how technology startups can accelerate their internationalization from inception. Simar also holds a Business Administration degree with specialization in Marketing from Univali (University of Vale do Itajaí) in Brazil, and he has a certification in International Trade and Negotiation Skills from Concordia University in Montreal, Canada.

Citation: Yoos, S. 2012. Market Channels of Technology

Startups that Internationalize Rapidly from Inception.

Technology Innovation Management Review. October 2012: 32-37. 